\title{
Aging Process Immunity and Its Relation with Periodontal Disease in Genetic Aspect
}

\author{
Pitu Wulandari \\ Doctoral Student Program \\ Faculty of Dentistry, Universitas Indonesia \\ Jakarta, Indonesia \\ puput_seven@yahoo.co.id
}

\author{
Elza Ibrahim Auerkari \\ Department of Oral Biology \\ Faculty of Dentistry, Universitas Indonesia \\ Jakarta, Indonesia
}

\begin{abstract}
One of the factors that related to biological aging in humans is genetic. The aging process can occur due to genetic accumulation and epigenetic modification that lead to progressive cellular damage and weakened tissue functions that causing limitation of abilities to maintain the balance/ homeostasis. Increased vulnerability to a number of inflammations due to the aging process is closely related to rising in prevalence and severity of periodontitis. The purpose of this paper is to analyze immunity of the aging process and its relation to periodontal disease in genetic aspect. Biological aging is affected by genetic variation that changes several genes that causing changes of several cell functions. Changes in DNA methylation are one of the mechanisms that contribute to the aging process, including the body immune system. Aging process influences both adaptive and innate body immune system. Changes in an immune and genetic system in the aging process could increase the severity of periodontal disease. As a conclusion, periodontal disease is an inflammation that related to aging. In the aging process, there are changes in the immune system that causes elder people more susceptible to periodontal infection. In addition, genetic and epigenetic factors also play a role in periodontal changes in elderly.
\end{abstract}

Keywords-aging, immune, genetic, periodontal

\section{INTRODUCTION}

The increasing age of life expectancy is closely related to the decline in mortality. Since the last century, a number of demographic data show remarkable changes related to health, longevity, illness, and death from populations around the world [1]. The total population in Indonesia is expected to reach 273.65 million by 2025 and in the same year the life expectancy is estimated to be 73.7 years, a considerable increase from the current 69.0 years [2].

Throughout life, the human body seeks to integrate the biological response in maintaining a comprehensive tissue in order to protect the body from the various threats that interfere with its survival. This integrated response is often influenced by genetic conditions. Genetic variations, especially those that slow the aging process, can partly explain why some individuals "can be healthy with age" [3]. Franceschi et al. put forward the idea of "the theory of tissue aging". This concept emphasizes a general reduction in the ability of the host response system to cope with various pressures, coupled with the progressive increase that occurs in the proinflammatory intrinsic environment during the aging process. This "inflamm-aging" state may be generated through continuous antigenic load and pressure changes affecting the immune system [4].

Biological aging in humans can occur due to genetic accumulation and epigenetic modification leading to progeny cellular damage, weakened tissue function, increased stress, and decreased physiological functioning, thus this limits the ability to maintain balance/homeostasis [5,6]. Ricklefs states that aging can decrease the individual's productivity and survival. If aging can increase susceptibility to extrinsic factors (infections), then aging can determine a person's lifetime [7].

The lifetime of one individual is closely related to the lifespan of the cells contained within his body. The period of cell division is estimated to occur as much as 50 to 100 times. The shortening of the telomere at the end of the chromosome also plays a role in the repetition of the DNA sequence (Deoxyribonucleic Acid), the sequence of six nucleotide bases (TTAGGG) found at the ends of all human chromosomes. The length is about $12 \mathrm{KBps}$ and the telomere will disappear when it has passed 100 cell divisions. Its length almost resembles cell life.6 Short telomeres can trigger cellular aging, and alter gene expression by local heterochromatin. Induced cellular aging and gene expression suppression. Disorders of histones and DNA modification in the telomeric and subtelomeric areas have been shown to result in loss of telomere length control [8].

The aging process will affect both the adaptive/specific and the innate/non-specific immune system. Apoptotic cell phagocytosis will be impaired in old age, i.e., the acceleration of neutrophil apoptosis during infection or inflammation; this contributes to the destruction of inflamed tissue due to unsanitary neutrophil apoptosis and the release of toxic substances. Neutrophil ability in elderly in killing bacteria will also decrease due to this. As a result, this could potentially reduce the infection control in older individuals $[9,10]$.

Increased susceptibility to a number of inflammatory, autoimmune diseases, or infectious diseases often occurs in the elderly as a result of the aging process, as well as the aging process which is also 
closely related to the increasing prevalence and severity of periodontitis $[11,12]$. Aging process can result in loss of gingival attachment and alveolar bone but the occurrence of these changes is only marginally significant clinically, except for significant periodontal inflammation seen in elderly.13 In short, periodontitis in the elderly can occur due to the consequent independent inflammation of the aging process so that the increased prevalence and severity of periodontitis in the elderly are only a reflection of the long exposure effects of periodontal pathogens [10].

Del-1 deficiency in periodontitis leads to excessive neutrophil infiltration and IL-17 due to inflammation of bone resorption. The Del-1 expression is reduced in gingival tissue in old age, as is the case with periodontitis due to genetic Del-1 deficiency. Del-1 and IL-17 were regulated reciprocally and the reverse expression of Del-1 and IL-17 was observed in human gingival biopsy samples, with Del-1 dominating in healthy gingiva and IL-17 in the inflamed gingiva [14]. This regulatory mechanism is impaired in old age due to a decrease in Del-1 mRNA and expression of the age-related protein [10]. The number of changes that occur in the elderly, especially the periodontal conditions makes the researcher interested in analyzing the immunity of the aging process and its relation to periodontal disease in the genetic aspects.

\section{LITERATURE REVIEW}

\section{A. Aging process and immunity}

According to the World Health Organization, "Elderly" is someone who has reached the age of 60 years and over [15]. Aging is an inevitable physiological change in living things and happens from time to time. Aging is a very complex multifactorial process and it is also a direct cause of disease and death in humans, making it one of the biggest questions among many biological phenomena $[6,16]$. The growth and aging process along with a number of physiological, genetic, and molecular changes can occur over time from fertilization to death. Aging is a period in the lifespan, whereas death can occur at any age. Aging is described as a decreased ability to respond to stress, increased homeostatic imbalances, and pathological incidence while death is a consequence of aging [17].

The theory of aging process is commonly divided into programming theory and error theory. Nowadays the theory of aging process can also be divided into evolution theory, molecular theory, cellular theory and systemic theory [16]. According to the program theory, aging process is the biological regulation time of the lifespan that begins from the stage of growth, development, maturation and old age, where this regulation will depend on changes in genes and nerve signals, endocrine, and immune responses responsible for maintaining homeostasis and activation of the immune response, while the error theory emphasizes that the environment affects the living organs so that it will induce progressive damage at varying levels (such as mitochondrial DNA damage, oxygen radical accumulation, or reciprocal relationships) $[6,16]$.

TABLE 1. CLASSIFICATION AND BRIEF DESCRIPTION OF THE MAIN THEORIES OF AGING [16].

\begin{tabular}{|c|c|}
\hline $\begin{array}{c}\text { Theory/ Biological } \\
\text { Level }\end{array}$ & Description \\
\hline $\begin{array}{l}\text { Evolution Theory } \\
\text { Mutation } \\
\text { - Accumulation } \\
\text { Disposable } \\
\text { Soma } \\
\text { - Pleiotropic } \\
\text { Antagonistic } \\
\end{array}$ & $\begin{array}{l}\text { Mutations affecting health in the elderly } \\
\text { are not selected. } \\
\text { Somatic cells are maintained only to } \\
\text { ensure successful reproduction, after } \\
\text { reproduction is done, soma is removed. } \\
\text { Useful genes at a young age are } \\
\text { damaged/disturbed in old age. }\end{array}$ \\
\hline $\begin{array}{l}\text { Molecular Theory } \\
\text { - Gene Regulation } \\
\text { - } \text { Codon } \\
\text { Restriction } \\
\text { - Errors that are } \\
\text { Disastrous } \\
\text { - Somatic } \\
\text { Mutation } \\
\text { Disdifferentiati- } \\
\text { on }\end{array}$ & $\begin{array}{l}\text { Aging causes a change in gene expression } \\
\text { that regulates development and aging. } \\
\text { The accuracy of mRNA translations is } \\
\text { poor because of the inability to encode } \\
\text { codons in mRNAs. } \\
\text { Decreased accuracy of gene expression in } \\
\text { aging causes an increase in the fraction of } \\
\text { abnormal proteins. } \\
\text { Accumulated molecular damage, } \\
\text { commonly DNA/genetic material. } \\
\text { The gradual accumulation of random } \\
\text { molecular damage that interferes with the } \\
\text { regulation of gene expression. }\end{array}$ \\
\hline $\begin{array}{l}\text { Cellular Theory } \\
\text { - Cellular aging - } \\
\text { Telomere } \\
\text { Theory } \\
\text { - Free Radical }\end{array}$ & $\begin{array}{l}\text { The phenotype of aging is due to an } \\
\text { increase in the frequency of weak cells. } \\
\text { Aging can occur due to telomere loss } \\
\text { (replicative aging) or cell stress (cell } \\
\text { aging). } \\
\text { Oxidative metabolism produces reactive } \\
\text { free radicals that can damage lipids, } \\
\text { proteins, and DNA. }\end{array}$ \\
\hline $\begin{array}{l}\text { - Wear and Tear } \\
\text { Apoptosis }\end{array}$ & $\begin{array}{l}\text { Accumulation of normal injury. } \\
\text { Programmed cell death from genetic or } \\
\text { genome crises. }\end{array}$ \\
\hline $\begin{array}{l}\text { Systemic Theory } \\
\text { - Neuroendocrine } \\
\text { - Immunologic }\end{array}$ & $\begin{array}{l}\text { Neuroendocrine changes in controlling } \\
\text { homeostasis cause aging that related to } \\
\text { physiological changes. } \\
\text { Decreased immune function in aging } \\
\text { results in decreased incidence of } \\
\text { infectious diseases but increases the } \\
\text { incidence of autoimmune diseases. } \\
\text { Assume a fixed amount of metabolic } \\
\text { potency for every living creature (live } \\
\text { fast, die young). }\end{array}$ \\
\hline
\end{tabular}

Nonspecific immune responses and its effector cells such as macrophages, polymorphonuclear leukocytes, and NK cells are generally considered less susceptible to the elder's immune system when compared with the adaptive immune system [18]. 
TABLE II. CHANGES IN NON-SPECIFIC IMMUNE SYSTEM ASSOCIATED WITH AGING [19]

\begin{tabular}{|l|l|l|}
\hline Type of Cells & $\begin{array}{c}\text { Increased non- } \\
\text { specific immune } \\
\text { systems associated } \\
\text { with aging }\end{array}$ & $\begin{array}{c}\text { Decreased non- } \\
\text { specific immune } \\
\text { systems associated } \\
\text { with aging }\end{array}$ \\
\hline Neutrophil & & $\begin{array}{l}\text { Oxidative burst } \\
\text { Phagocyte capacity } \\
\text { Bactericidal activity }\end{array}$ \\
\hline Macrophage & & $\begin{array}{l}\text { Oxidative burst } \\
\text { Phagocyte capacity }\end{array}$ \\
\hline Dendritic Cells & & $\begin{array}{l}\text { Capacity to stimulate } \\
\text { T-cells against } \\
\text { specific antigen }\end{array}$ \\
\hline $\begin{array}{l}\text { Cytokine and } \\
\text { Chemokine }\end{array}$ & $\begin{array}{l}\text { Serum levels of IL- } \\
6, \text { IL-1 } \beta \text { and TNF- } \alpha\end{array}$ & \\
\hline
\end{tabular}

The adaptive immune system will decrease along with aging, resulting in a decrease in the production of naive $\mathrm{T}$ cells (T0), decreased antigen presenting receptors, damage to $T$ cell signal transduction resulting in induced cytokine pattern changes, and reduced clonal expansion and antigen-specific $\mathrm{T}$ and $\mathrm{B}$-cells function [20]. The decline in the production of naive $\mathrm{T}$ cells is partly related to the involution of the thymus in aging. In addition, the frequency of lymphoid B progenitor cells will decrease with aging, so that hematopoietic stem cells will lean towards myeloid in lymphoid progenitor cells [21]. The ability of human hematopoietic cells to proliferate is related with age, causing shortening of telomeres even though age does not affect erythrocytes and myeloid progenitors. However, this does not seem to be the case in B-cells. Generally, decreased B-cells production causes decreased amount of mature B-cells [22].

Loss of B-cell function leads to decreased expression of co-stimulating molecules such as CD40 or CD27. In the elderly, CD4+ will produce low levels of IL-2 and decreased CD40 expression, which is an important factor in the interaction of $\mathrm{T}$ cells and $\mathrm{B}$ cells. The loss of B-cell function in aging causes the frail immune system in the elderly [19,23].

B. The role of genetic and epigenetic in aging process

It is very rare for human's age to reach 120 years old. Most humans die from various diseases before reaching the age of 120 years. Lately, the average age of humans appears to be shorter than the maximum age. One of the factors that affect age is genetic.24 Human biological changes include changes in tissues, cells, and molecules of the body. This cannot be stopped, so the process to prevent or slow down aging is still a dream that is difficult to realize $[25,26]$.

One of the aging theories, the theory of evolution, predicts that certain genes play a role in early life with an undesirable effect on later life (pleiotropic antagonists theory) or genes that play a role in longevity (disposable soma theory) [16,25]. Biological aging can be affected by genetic variations that alter some genes causing changes of several cell functions. Genetic variation (called polymorphism when it occurs in $>1 \%$ of the population) is transmitted from the parents to their children. Biological aging is also affected by regulatory molecules that alter the transcriptional patterns of some genes [24,25,27]. The eukaryotic gene is in the nucleus regulated by the chromosomes. Each chromosome is formed by a single DNA molecule (Deoxyribonucleic acid) associated with histone and non-histone proteins. Genes are part of DNA that can or cannot produce several types of RNA (Ribonucleic acid) $[25,27]$.

DNA and Histones can withstand some chemical reactions such as methylation or acetylation that can switch genes on and off, whereas this process can also alter cell function. This chemical change function is known as an epigenetic modification. The epigenetic pattern that occurs in the elderly gene can be passed down to the next generation [25]. Some genes, such as LMNA (Lamin A/C), which mutant version causes reduced longevity, can be used to find clues to fix agerelated diseases [28]. DNA methylation is the best epigenetic modification. This provides a stable and a hereditary component of epigenetic regulation [29].

In mammals, almost all DNA methylation occurs in cytosine residues of $\mathrm{CpG}$ dinucleotides. DNA methylation is part of $\mathrm{CpG}$, the region of the highdensity genome in $\mathrm{CpGs}$ dinucleotides that correlates with transcriptional containment [29]. Although the rate of genome methylation decreases with age, the $\mathrm{CpG}$ portion of many specific promoter regions, typically non-methylated, becomes methylated. These promoters include several tumor suppressor genes such as CDKN2A, LOX, RUNX3, and TIG1. This observation is consistent with the assumption that age-related methylation changes related to the vulnerability of cancer in the elderly [30].

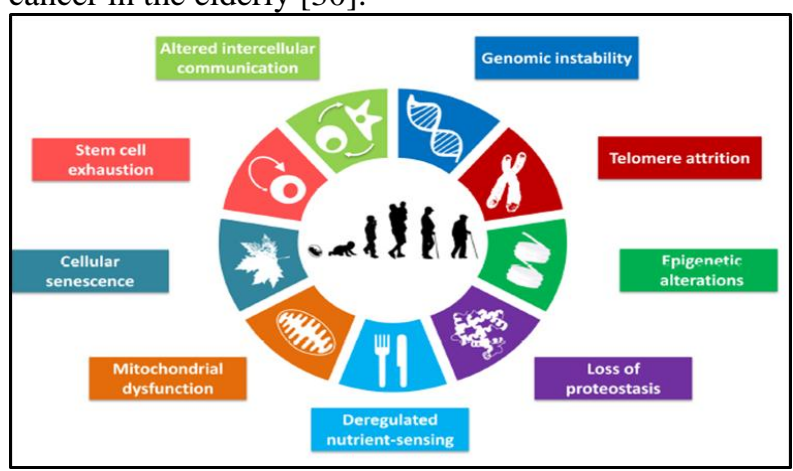

Figure 1. The hallmark of aging [26].

Normal aging and age-related pathology are associated with the attrition of telomeres. Recently, human SIRT6 protein has been found to be NADpdependent H3K9 deacetylase, which is specifically associated with telomeres. SIRT6 appears to be necessary for the stability of Werner's syndrome protein (WRN), a RecQ helicase that mutates in premature aging (progeroid) occurring in Werner's syndrome. The depletion of SIRT6 causes telomere dysfunction and premature cellular senescence [8].

\section{Genetic relation to periodontal disease and aging}

An inflammatory response occurs through many processes in the body and it is essential for human 
survival. An inflammatory response is required as a form of body defense against periodontal pathogens and it plays a role in wound healing as in response to injury or infection where acute inflammation occurs immediately when an antigen enters the body, where this usually lasts briefly. However, when inflammation persists, it subsequently becomes chronic because host immune and inflammatory responses are unable to eliminate or exclude pathogens that initiate the disease, one of which is periodontal disease [31].

Periodontal disease is an inflammatory disease and is commonly known as gingivitis and periodontitis, caused by periodontal pathogens [32]. The diagnosis of periodontitis is based on the clinical findings of bleeding on probing, periodontal pocket formation and occurrence of clinical attachment loss [33]. Prevention of infectious diseases is one of the steps that must be done to create a healthy condition in the elderly [34].

Dendritic cells in the elderly show impaired capacity in the ingestion of apoptotic cells, although there is an elevation in the pro-inflammatory responses and antigen reactions. Therefore, dendritic cell maturation disorders during aging can alter the balance between tolerogenic and immunogenic functions [35]. The speed of neutrophil movement to the site of infection, known as chemokinesis, does not change in the elderly, although on the contrary, the chemotaxis (i.e., response to the stimulus) is impaired [36,37]. Naive T-cells in the elderly are less responsive to IL-6 signals thus reducing their ability becoming Th2 cells that assist in B-cells differentiation [38,39].

One of the most important factors in determining the etiopathogenesis of periodontitis is the genetic factor [40]. Changes in the path of the adaptive immune system in the elderly show that in the aging process of gingival tissue, there is a significant increase in the expression of the main gene pathway of histocompatibility complex II, including the intracellular molecules necessary to process the original proteins into short peptide fragments. HLA molecules play an important role in the development of immune responses by presenting bacterial antigens to effector cells of the immune system. The MHC gene shows signs of polymorphism characterized by increasing allele diversity. DR allele encodes $\alpha$ chain of HLA-D heterodimers belonging to class II MHC that can determine increased susceptibility to infection [41].

Changes in DNA methylation are one of the mechanisms that contribute to the aging process, including the body immune system [42]. One's epigenetic changes also play a role in aging. Aging itself contributes to the initiation of cellular damage processes, including epigenetic modifications of gene expression that can affect normal cell functions [38]. Based on gerontogene or replicative aging (Hayflick limit and telomere shortening), the number of progenitor cells was decreases. This results in decreased cell component along with the reduction of cellular reserves and protein synthesis. This affects the oral epithelium, in which they (as part of the gingival epithelium) get thinner with decreased level of keratinization [43].

In elderly, thinning and decreased height of the gingival epithelium always occur. The thinning of the gingival epithelium will increase the permeability of the epithelium to the entry of the antigen so that this will cause the resistance to the antigen decreases. This will affect the periodontal condition in the long term $[44,45]$.

\section{DISCUSSION}

The environment has a role in the biological aging process as environmental factors can disrupt the homeostatic balance. For example, pollutants from the environment, e.g. air pollution may interfere with biological mechanisms (inflammatory phenomena, oxidative stress, metabolic disorders, and genetic/epigenetic modification) that involved in the aging process [46].

In chronic inflammation, there is an increase in proinflammatory cytokines in response to physiological and environmental stresses to maintain the immune system at lower activation levels. The chronic condition of inflammation will activate the immune system on an ongoing basis with age, so this is also called as "inflamm-aging". Although the mechanism is not yet identified clearly, the pro-inflammatory phenotype of the cell and the increased inflammatory response that occurs with age play a role in the initiation and progression of age-related diseases such as type II diabetes, Alzheimer disease, cardiovascular disease, malaise, sarcopenia, osteoporosis, cancer, and this also includes oral diseases, especially periodontitis [10].

Kim et al. concluded that stem cell aging phenomenon causes a decrease in the size of pluripotent hematopoietic cells that derived from stem cells, decreased cell renewal capacity, decreased differentiation and engraftment (new blood cell formation) and imbalance in lymphoid and myeloid. These results in immune dysfunction decreased immune function due to aging, and increased prevalence of myeloproliferative disease [47].

Decreased age-related phagocytosis and microbicidal activity in neutrophils and macrophages result in uncontrolled growth of periodontal bacteria into the dysbiosis community. Involution of the thymus is characterized by reduced overall organ size and replaces the cortex function and medulla tissue by fat. The perivascular space of the human thymus is elevated in old age, this results in decreased thymopoiesis (a process in the thymus where the thymocytes will differentiate into mature $\mathrm{T}$ lymphocytes). In cellular immunity, increased age causes rapid decreases of cellular functional immunity. Functional immunity should be distinguished from the absolute cell numbers, as most studies do not show age-related changes in absolute leukocyte counts (lymphocytes, monocytes, natural killer cells or granulocytes) [48,49]. Unstimulated memory $\mathrm{T}$-cells ratio increases with age. This indicates that memory $\mathrm{T}$-cells are retained, but the 
ability of these cells to respond to new antigens decreases with age [1].

In the elderly, there is DNA dimethylation that occurred repeatedly, e.g. the movement of the genetic element and local hypermethylation of the gene promoter transcripted by RNA II polymerase e.g. rRNA. Aging is accompanied by the formation of a nucleus region called SAHF (senescence-associated heterochromatin foci). During aging, DNA activity of methyltransferase 1 and DNA methyltransferase $3 \mathrm{a}$ is reduced by deacetylase from SIRT1, while histone deacetylase is increased. This change causes epigenetic changes that cause gene expression to change and cause aging [27]. Issa et al. indicate that high methylation causes an increase in cell turnover. Methylation abnormalities may play some roles in tumor formation, for this is possible through gene knockdown mechanism $[27,50]$.

Aging is also considered to be associated with increased prevalence and severity of periodontitis, although the cause is still not yet clearly understood. Among the plausible mechanisms in which aging may contribute to increased susceptibility to periodontitis is a change in the immunity and inflammation of agerelated host [10]. Once the antigen attacked the host, inflammatory response will follow. Recent research has shown that bacteria can affect the chromatin structure and the transcriptional program of host cells that are affected by various epigenetic mechanisms. Epigenetics will determine gene expression and selective activation or inactivation of genes. This event will modulate the inflammatory mediator to express the cytokine so that it plays a role in the pathogenesis of inflammatory diseases [51,52].

In the case of periodontal disease, an overexpression of pro-inflammatory cytokines (IL-1, IL-4, IL-6 and IL10) occurred. Epigenetics such as hypomethylation and histone acetylation are associated with overexpression of inappropriate genes. Gomez et al., suggest that the hypomethylation of the IL-6 cytokine gene in the periodontium of periodontitis patients will lead to overexpression of cytokines in inflamed tissues [53].

The increasing severity of periodontitis in most populations believed to be closely related to aging. Changes that occur in the aging process, from the ability of innate and adaptive immune systems in recognizing the microbial transition on biofilm, to the process that produce changes in cellular and humoral cell level, where severe inflammation in the periodontium of elderly may have secondary effects resulting from the inability to obtain an appropriate and effective immune response as a result of age changes, resulting in immune inefficiency leading to chronic persistence of pathogens and destructive inflammation [3].

As a conclusion, periodontal disease is an inflammatory disease associated with aging. In the aging process, immune system changes occur in both adaptive and innate immune systems; this causes older individuals to be more susceptible to periodontal disease. Other than the immune system, genetic and epigenetic factors also contribute to periodontal changes in the elderly.

\section{ACKNOWLEDGEMENT}

Acknowledgments are addressed to the Minister of Research, Technology and Higher Education of Indonesia, at the expense of this study was derived from DRPM Directorate General of Strengthening Risbang in 2017.

\section{REFERENCES}

[1] N.U. Munoz, J.M. Sedivy, "Epigenetic control of aging," Antioxidants \& Redox Signaling, vol. 14, pp. 241-259, 2011.

[2] BAPPENAS. (2025) Angka Harapan Hidup Penduduk Indonesia 73,7 Tahun, 2015. Available: http://www.bappenas.go.id/node/142/1277/tahun-2025-angkaharapan-hidup-penduduk-indonesia-737-tahun/.

[3] J.L. Ebersole, C.L. Graves, O.A. Gonzalez, "Aging, inflammation, immunity and periodontal disease," Periodontol 2000, vol. 72, pp. 54-75, 2016.

[4] C. Franceschi, S. Valensin, M. Bonafe, "The network and the remodeling theories of aging: historical background and new perspectives," Exp. Gerontol., vol. 35 pp. 879-896, July 2000.

[5] D.G.A. Burton, "Cellular senescence, ageing and disease," Age (Omaha), vol. 3, pp. 1-9, 2009.

[6] D.C. Park, S.G. Yeo, “Aging,” Korean J. Audiol., vol. 17, pp. 39-44, 2013

[7] R.E. Ricklefs, "The evolution of senescence from a comparative perspective," Funct. Ecol., vol. 22, pp. 379-383, 2008.

[8] E. Michishita, R.A. McCord, E. Berber," SIRT6 is a histone H3 lysine 9 deacetylase that modulates telomeric chromatin," Gerontology, vol. 452 (7186), pp. 492-496, March 2008.

[9] J. Ebersole, M. Steffen, M. Reynolds, "Differential gender effects of a reduced calorie diet on systemic inflammatory and immune parameters in nonhuman primates," J. Periodontal Res. vol. 43 (5), pp. 500-507, October 2008.

[10] G. Hajihangelis, "Aging and its impact on innate immunity and inflammation: implication for periodontitis," J. Oral Biosci., vol. 56 (1), pp. 30-37, September 2013.

[11] G. Hajishengallis, "Too old to fight? Aging and its toll on innate immunity," Mol. Oral Microbiol., vol. 25(1), pp. 2-17, January 2010.

[12] R. Solana, R. Tarazona, I. Gayoso, O. Lesur, G. Dupuis, T. Fulop, "Innate immunosenescence: effect of aging on cells and receptors of the innate immune system in humans," Seminars in Immunology, vol. 24, pp. 331-341, 2012.

[13] E.A. Huttner, D.C. Machado, R.B. Oliveira, A.G.F. Antunes, E Hebling, "Effects of human aging on periodontal tissues," Spec. Care Dentist, vol. 29(4), pp. 149-155, 2009.

[14] M.A. Eskan, R. Jotwani, T. Abe, "The leukocyte integrin antagonist del-1 inhibits IL-17-mediated inflammatory bone loss," Nature Immunology, vol. 13(5), pp. 465-473, February 2012.

[15] Mahkamah Konstitusi. (1998) Undang-Undang Republik Indonesia Nomor 13 Tahun 1998 tentang Kesejahteraan Lanjut Usia. Available: http://portal.mahkamahkonstitusi.go.id/ eLaw/.../uu13 1998.pdf.

[16] B.T. Weinert, P.S. Timiras, "Physiology of aging. Invited review: theories of aging," J Appl. Physiol., vol. 95, pp. 17061716, 2003.

[17] L.A. Gavrilov, N.S. Gavrilova, "Evolutionary theories of aging and longevity," Sci. World J., vol 2, pp. 339-356, July 2001.

[18] A. Panda, A. Arjona, E. Sapey, "Human innate immunosenescence: causes and consequences for immunity in old age," Trends Immunol., vol. 30(7), pp. 325-333, July 2009.

[19] D. Weiskopf, B. Weinberger, L.B. Grubeck, "The aging of the immune system," Transplant International, vol. 22, pp. 1041 1050, June 2009.

[20] N.P. Weng, "Aging of the immune system: how much can the adaptive immune system adapt?” Immunity, vol. 24, no.25, pp. 495-499, May 2006. 
[21] H. Geiger, G.D. Haan, M.C. Florian, "The ageing haematopoietic stem cell compartment," Nature Review Immunology, vol. 13(5), pp. 376-389, May 2013.

[22] M.P. Cancro, "B cells and aging: gauging the interplay of generative, selective, and homeostatic event," Immunological Review, vol. 205, pp. 48-59, 2005.

[23] Y. Aydar, P. Balogh, J.G. Tew, A.K. Szakal, "Age-related depression of FDC accessory functions and CD21 ligandmediated repair of co-Stimulation," Eur. J. Immunol., vol. 32, pp. 2817-2826, August 2002

[24] H. Shimokata, F. Ando, "Aging-related genes," Anti-Aging Medicine, vol. 9(6), pp. 185-191, October 2012.

[25] I.B.M. Cruz, "Genetics of aging and its impact on human longevity: theories and evidences that helps to prevent ageassociated diseases," PAJAR - Pan American Journal of Aging Research, vol. 2(1), pp. 3-14, January 2014.

[26] C.O. Lopez, M.A. Blasco, L. Partridge, M. Serrano, "The hallmarks of aging." Cell, vol. 153(6), pp. 1194-1217, June 2013.

[27] A.A. Moskalev, A.M. Aliper, M.Z. Smit, A. Buzdin, A. Zhavoronkov, "Genetics and epigenetics of aging and longevity," Cell Cycle, vol. 13(7), pp. 1063-1077, April 2014.

[28] A. Zhavoronkov, M.Z. Smit, K.J. Guinan, M. Litovchenko, A. Moskalev, "Potential therapeutic approaches for modulating expression and accumulation of defective lamin $\mathrm{A}$ in laminopathies and age-related diseases," J. Mol. Med., vol. 90, pp. 1361-1389, September 2012.

[29] L.G. Jackson, C. Beard, R. Possemato, "Loss of genomic methylation causes p53-dependent apoptosis and epigenetic deregulation," Nature Genetic, vol. 27(1), pp. 31-39, January 2001.

[30] K. So, G. Tamura, T. Honda, "Multiple tumor suppressor genes are increasingly methylated with age in non-neoplastic gastric epithelia," Cancer Sci., vol. 97(11), pp. 1155-1158, November 2006.

[31] L.T. Yucel, T. Bage, Inflammatory mediators in the pathogenesis of periodontitis," Expert Reviews in Molecular Medicine, vol.15, pp. 1-22, August 2013.

[32] N. Silva, L. Abusleme, D. Bravo, "Host response mechanisms in periodontal diseases," J. Appl. Oral Sci., vol. 23(3), pp. 329355, February 2015

[33] A. Savage, K.A. Eaton, D.R. Moles, I. Needleman, "A systematic review of definitions of periodontitis and methods that have been used to identify this disease," J. Clin. Periodontol, vol.36, pp. 458-467, March 2009.

[34] D. Boraschi, M.T. Aguado, C. Dutel, "The gracefully aging immune system," Science Translation Medicine, vol.5(185), pp. 1-9, May 2013

[35] A. Agrawal, A. Sridharan, S. Prakash, H. Agrawal, "Dendritic cells and aging: consequences for autoimmunity," Expert Rev. Clin. Immunol., vol.8(1), pp. 73-80, January 2012.

[36] I. Wessels, J. Jansen, L. Rink, P. Uciechowski, "Immunosenescence of polymorphonuclear neutrophils," MiniReview the Scientific World Journal, vol. 10, pp. 145-160, December 2009

[37] O. Iizawa, H. Akamatsu, Y. Niwa, "Neutrophil chemotaxis, phagocytosis, and generation of reactive oxygen species show a hierarchy of responsiveness to increasing concentration of $\mathrm{n}$ formation-met-leu-phe," Biol. Signals, vol. 4, pp. 14-18, September 1994.

[38] S. Swain, D.K. Clise, L. Haynes, "Homeostasis and the ageassociated defect of CD4 T cells," Semin. Immunol., vol. 17(5), pp. 370-377, October 2005 .

[39] W. Zhang, V. Brahmakshatriya, S.L. Swain, "CD4 T cell defects in the aged: causes, consequences and strategies to circumvent," Experimental Gerontology, vol. 54, pp. 67-70, January 2014.

[40] S.M. Słotwińska, "The genetic determinants of immunologic response in periodontitis," Central European Journal of Immunology, vol. 36(4), pp. 275-278, 2011

[41] H.O.M. Devitt, "Discovering the role of the major histocompatibility complex in the immune response," Annu. Rev. Immunol., vol. 18, pp. 1-12, 2000.

[42] F.J. Rang, J. Boonstra, "Causes and consequences of age-related changes in DNA methylation: a role for ROS?" Biology, vol. 3, pp. 403-425, May 2014.
[43] D.V.U. Van, "Effect of age on the Periodontium," J. Clin Periodontol., vol. 11. pp. 281-294, April 1983.

[44] M.J. Novak, K.F. Novak, Chronic periodontitis. In: Carranza FA, ed. Carranza's Clinical Periodontology, $11^{\text {th }}$ ed., Missouri: Elsevier Saunders, 2012, pp. 160-162.

[45] I. Needleman, Aging and the periodontium. In: Carranza's Clinical Periodontology. Saunder's, 2012, pp. 40-44.

[46] R. Zhao, "Immune regulation of osteoclast function in postmenopausal osteoporosis: A critical interdisciplinary perspective," International Journal of Medicine Sciences, vol 9(9), pp. 825-832, October 2012.

[47] M.J. Kim, M.H. Kim, S.A. Kim, J.S. Chang, "Age-related deterioration of hematopoietic stem cells," International Journal of Stem Cells, vol. 1(1), pp. 55-63, October 2008

[48] G.R. Persson, "What has ageing to do with periodontal health and disease," International Dental Journal, vol. 56, pp. 240-249, 2006.

[49] K.G. Flores, J. Li, G.D. Sempowski, B.F. Haynes, L.P. Hale, "Analysis of the human thymic perivascular space during aging," J. Clin. Invest., vol. 104, pp. 1031-1039, Septembe 1999.

[50] J.P. Issa, N. Ahuja, M. Toyota, M.P. Bronner, T.A. Brentnall, "Accelerated age-related $\mathrm{CpG}$ island methylation in ulcerative colitis," CANCER Research, vol. 61(713), pp. 3573-3577, May 2001.

[51] H. Bierne, M. Hamon, P. Cossart, "Epigenetics and bacteria infections," Cold Spring Harb Perspect Med, vol. 2, pp. 1-16, 2012

[52] R. Feil, "Environmental and nutritional effects on the epigenetic regulation of genes," Mutation Research 600, Science Direct, vol. 600(1), pp. 46-57, July 2006.

[53] R.S. Gomez, W.O. Dutra, P.R. Moreira, "Epigenetics and periodontal disease: future perspectives," Inflammation Research, vol. 58, pp. 625-629, April 2009. 